\title{
Using Internal Marketing to Extract Value: An Empirical Study on the Algerian Private Health Organizations
}

\author{
Nahed Hebbaz ${ }^{1} \&$ Khalil Chergui ${ }^{1}$ \\ ${ }^{1}$ Faculty of Economics, Larbi Ben M'hidi University, Oum El Bouaghi, Algeria \\ Correspondence: Khalil Chergui, Faculty of Economics, Larbi Ben M'hidi University, Oum El Bouaghi, Algeria. \\ E-mail: khalil.reo@gmail.com
}

Received: January 13, 2019

Accepted: February 20, 2019 Online Published: March 11, 2019

doi:10.5539/ijbm.v14n4p182

URL: https://doi.org/10.5539/ijbm.v14n4p182

\begin{abstract}
:
The aim of this study is to examine the relationship of the internal marketing with extracting value in the Algerian private health organizations. This study was conducted based on a psychometrically validated questionnaire which designed and distributed to a random sample of 169 Algerian private health organizations managers. 136 managers filled the questionnaire. Confirmatory Factor Analysis has been used as statistical methods to analyse the three developed hypotheses . In particularly, we found that: (a) Algerian private health organizations use internal marketing to extract value. (b) There is statistically significant relationship between "Internal Marketing (IM)" and "extract value" amongst the Algerian private health organizations (C) There is a statistically significant difference amongst the Algerian private health organizations toward extract value due to experience of organizations.
\end{abstract}

Keywords: internal marketing, extract value, Algerian private health organizations, Algerian private medical-surgical organizations

\section{Introduction}

The advent of the knowledge economy and the shift towards a technology based competition in the global markets has led to a growing importance of innovation for organizations' growth. In particular, market value of organizations appears to rely increasingly on intangible assets, notably on human resources, which makes internal marketing development a strategic issue for organizations.

Different compelling arguments have been advanced for a better understanding and appreciation of the IM value and its potential impact on business value. It has been shown that any type of organization can use IM to facilitate the implementation of its external marketing strategy or any other organizational strategies.

IM is a strategic approach to human resources management in order to focus on customer tendencies and achieve competitive advantages for the organizations.

\subsection{Research Problem}

Learning and knowledge management are ways to invest the potential of the staff, which are related concepts. New knowledge is the product of learning, when applied; it contributes to the formation of a higher level of vision and learning. Knowledge consolidation is achieved through innovative learning behaviors that involve cultural changes in mental attitudes and intellectual in individual and collective units (Escaffere, 2002, p.79).

Some organizations are applying internal marketing to enhance the degree of innovation in response to a shortened product / service lifecycle. The increasing demand for new products / services and ideas in the knowledge economy represents a major challenge to the enterprise's innovative capabilities, making some organizations motivate their employees to market Their work is in support of innovation, coordination and cooperation between all departments to make innovation an activity in which every employee of the institution and every client who has been able to market his ideas to serve the institution. The role of internal marketing at the level of innovation management is to spread innovation within the enterprise and to motivate staff to participate in the process of generating ideas from the operational level. (Pervais\& Mohammed, 2002, pp.158-162).

Today, IM is still a topic of major interest for many researchers and is an organizational variable that should be 
understood and constantly monitored for the welfare of any organization. In our principal thesis there is no best way to use IM, rather, the value of the various means to use and benefit from IM depends on firm strategy and the competitive landscape.

Health work is not different from the business world, where knowledge management and learning require investment of manpower and capital. The internal marketing mix helps to transform the knowledge discovered into practical knowledge through the organization's various productive processes, which are characterized by innovative resources. These include ideas, creations, new product / service concepts developed by employees as well as those developed by business networks and marketing relationships with them, as well as procedures and systems of business performance and methods used to turn ideas into market services / products. Technical knowledge, motivational capacities, management skills and methods, power patterns, degree of authority, internal and external communication are associated successfully or failure of innovative projects. (Nobre \&al, 2012, p328)

Algerian private health organizations are ones of organizations where the IM has not received much attention. This research will study the relationship between IM and extract value by using IM mix and activities on a simple random sample of the Algerian private health organizations.

\subsection{Research Hypotheses}

H1: Algerian private health organizations use internal marketing to extract value;

H2: There is statistically significant relationship between "Internal Marketing (IM)" and "extract value" amongst the Algerian private health organizations;

H3: There is a statistically significant difference amongst the Algerian private health organizations toward extract value due to experience of organizations.

\subsection{Research Objectives}

- Taking note of the concept of internal marketing and highlighting its importance for Algerian private health organizations;

- Recognize the degree of application of the Algerian private health organizations for internal marketing to extract value;

- To test the relationship between using internal marketing and extract value in Algerian private health organizations;

- To test the relationship between the experience of Algerian private health organizations and the extraction of value using internal marketing;

- To provide a recommendations for management of Algerian private health organizations regarding extract value by using internal marketing.

\subsection{Previous Studies}

1. Ahmed K Pervais., Rafik Mohammed, Internal Marketing: Tools and Concepts for Customer- Focused Management, $1^{\text {st }}$ ed, Butterworth-Heinemann, Oxford, 2002.

This study aims at clarifying how to use internal marketing in implementing the strategies of the organization. The study concluded that internal marketing plays a major role in total quality management, innovation and the development of knowledge management areas.

2. Isabel Sanchez-Hernandez., David Grayson, Internal Marketing for Engaging Employees on the Corporate Responsibility Journey, Intangible Capital, IC, vol.8, No.2, 2012, pp275-307.

The purpose of this study is to explore the role of internal marketing in engaging employees within the company's responsibilities. The study concluded that internal marketing can help managers make profits through the social and environmental potential of employees and integrate the concerns and skills of employees into the overall responsibilities and efforts of the organization.

3. David Ballantyne, Internal relationship marketing: a strategy for knowledge renewal. International Journal of Bank Marketing, 2000, Vol.18, No.1, p p 274-286

The study reached a number of results, the most important of them is that internal marketing requires activation of the learning process and gains its legitimacy through external market orientation. 


\section{The Theoretical Framework of the Study}

\subsection{Internal Marketing}

Internal marketing is attracting, developing, motivating and retaining qualified employees through job-products that satisfy their needs. Internal marketing is the philosophy of treating employees as customer, and it is the strategy of shaping job- products to fit human needs. (Berry\& Parasuraman, 1991, p151). IM consider being a management tool for converting human capital into value by defining and capturing new knowledge. For example, (David Ballantyne) defined internal marketing as a relationship-mediated strategy for the purpose of knowledge renewal. This approach involves planned preparatory learning phases, and innovative action phases, through which 'taken for granted' organizational knowledge is challenged by employees and changed in ways that impact positively on external marketing performance. (Ballantyne, 2004, p3)

IM is generally intervening in how organizational meaning for knowledge is constructed and reconstructed.

\subsubsection{Internal Marketing Mix}

Given the balance approach that governs the relationship between the organization and the employee, the organization must adopt broader roles for the continuation of this interaction, in order to achieve the objectives of both parties through the internal marketing mix (internal product, internal price, internal distribution, internal promotion). In terms of its internal marketing literature, many researchers (Berry, 1981; Flipo, 1981; Kale 2006; Johnson \& Scott, 2006) see the elements of the marketing mix (04Ps) being applied effectively to the internal market (Tanhaei\& al, 2013, pp340-341)

\section{-Internal product}

The internal product represents the work of linking the contents of the job, the qualifications required to it, and the incentives prescribed in a form that meets the needs and desires of the employees and the organization, which is a means of creating the internal affiliation.

In view of the law of total balance that governs the exchange between the organization in its entirety (its image, culture, relations between its members, organizational structure) and the value that the job possesses in all its components (tasks, duties, benefits and privileges) and the employee with all his (preparations, skills, Commitment to work and efforts to achieve the goals), the organization should treat the functions as products that go beyond the tasks to be done and pay attention to marketing them well to their employees and focus on their benefits, by considering training needs, participation in decision-making and opportunities for career advancement, which facilitates the process of attracting, motivating and retaining staff.

\section{-Internal price}

The internal price refers to processes that create a balance between use and value in return for the cost to both the employee and the organization, whether hiring or changing jobs and assigning new tasks, which in turn provide opportunities for salary increases, incentives, career excellence and leadership. The internal price is therefore seen as a way to promote jobs and strengthen staff's ability to negotiate in the job market by acquiring new skills. (Pervais\& Mohammed, 2002, p28)

Internal marketing pays great attention to the psychological aspects of the interaction and the relationship between the "price" of the employee and the procedures of achieving the institution's strategy. He points out that value creation is done through internal relationships and a strengthened working relationship, so that the employee has the greatest potential to experience interactions, relationships and opportunities. (Dunne\& Barne, 2000, p205)

\section{-Internal distribution}

Distribution in the internal context is the intersection between the internal and external marketing mix of the service, and plays an important role in the match between them, the workplace in the service organization may be shared between the employee and the customer, the internal distribution is a way to draw attention to differences in staff response to strategic objectives. (Wiley\& Parker, 2005, p. 854)

The quality of the workplace affects the relationships and interaction between the parties and determines the extent of staff cooperation and employment. A high quality environment is characterized by high trust, commitment and reciprocity among the parties involved. The work environment can be described as an axis of organizational culture in which enhanced quality behaviors become a reflection of employee work. Identify this environment and the associated quality enhancement factors represent the ultimate source of competitive advantage in the dynamic environment. (Pervais\& Mohammed, 2002, p. 114) 


\section{-Internal promotion}

Internal promotion is defined as "a job to generate skills, knowledge and awareness of strategic change issues" (Pervais\& Mohammed, 2002, p. 42). It refers to how the organization's strategy is communicated to employees (selling the organization internally) and making them understand how their functions fit into the implementation of marketing programs in general. Internal promotion takes the form of speeches, screenings and newsletters. (Hollensen, 2010, p. 547)

Internal communication, stimulation, empowerment are the key promotion elements that are key tools available to connect management and employees on the one hand and between employees and customers on the other. (Kotler\& Keller, 2012, p. 146)

\subsubsection{Internal Marketing Activities}

Internal marketing activities are derived from general marketing assumptions. According to (Collins \& Payne), internal marketing activities include internal market research and fragmentation. (Percy \& Morgan) believes that internal marketing activities are the development of strategies that allow the application of elements of external marketing mix (product, price, distribution, promotion) to the internal market (employees).( Sanchez-Hernandez\& Grayson, 2012, p. 282)

\section{- Internal Marketing Research}

Internal Marketing research is to search and optimize the use of information from all available sources and administrative levels to test them for marketing needs, relying on traditional methods of marketing research, ranging from simple surveys such as questionnaires, interviews, and direct dialogues to accurate collection of valuable information to reach factors that determine the nature of internal relationships for the purpose of creating homogeneous groups or sectors. (Muntaynu\& al, 2014, p. 12).

\section{- Internal market fragmentation}

The fragmentation of the internal market must be made to identify the differences between the targeted individuals and divide it into sectors where each sector is similar in desires, needs and motives in order to design a program suitable for each sector. (Jobber, 2001, p. 185)

\subsection{Internal Marketing to Extract Value}

internal marketing contributes to determining the type of role innovation agents must undertake to implement innovation strategies, assess skills to implement specific innovation projects, promote internal and external public relations supporting innovation, manage information to provide an environment conducive to innovation, build high levels of teamwork and mutual trust between team members, assess the behavior of managers and staff in terms of guidance, objectives and expectations of others.(Pervais\& Mohammed, 2002, pp158-162)

IM is a way of learning how to use the everyday experience of skilled employees creatively, because it represents organization's hidden (tacit) knowledge - and this kind of knowledge capital is difficult for competitors to copy (Wikstrom \& Normann, 1994; Nonaka \& Takeuchi, 1995; Inkpen, 1996; Sveiby, 1997).

Internal marketing enhances proper performance of knowledge management and allows the enterprise to enhance the service of employees and customers by building internal competencies and customer knowledge. It also requires developing the foundations of knowledge and learning from organizations exchange beliefs, attitudes and vision to create value in the institution. Ballantyne has linked knowledge management and internal marketing through two internal marketing approaches: (Ballantyne, 2000, pp. 277-284).

- Marketing business transactions: aims to meet the needs of customers profitably, for the purpose of: 
- Acquire new knowledge: through the exploitation of external sources;

- Legalize knowledge: apply individual resources from business knowledge to solve customer problems, create new opportunities and change internal procedures.

- Marketing relationships: with the aim of creating mutual value with customers or other stakeholders, to:

- Generate new knowledge: through multi-functional project groups, creative approaches, innovation centers, quality improvement teams, etc., while considering internal marketing intelligence as data;

- Knowledge transfer: through team-based learning programs, skills development workshops, assessment workshops, etc., and disseminated through the internal client chain to create value for external customers.

Internal marketing also contributes to innovation support through measures that are more powerful than any "compulsory" programs by:

- examine the hierarchy, basic and subsidiary processes and linkages: to assess or prioritize obstacles to innovation activities;

- Launching creative energy within each employee through a staff empowerment approach;

- Examining the necessary duties and defining the roles that innovation factors play to implement their strategies.

This links strategic implementation is related to the specific abilities and skills of each individual.

\section{Research methodology}

A simple random sample is used where 169 managers or directors of the companies were surveyed as recommended by Bontis (1998) and Bukh et al (1999).

In this study, a limited society of 169 Algerian private medical-surgical organizations was used. A total of 136 managers responded. The questionnaire included (42) questions and was processed by SPSS. V 0.20.

The following table describes the dimensions of the study and the number of the related items for each dimension.

Table 1. Dimensions of the research

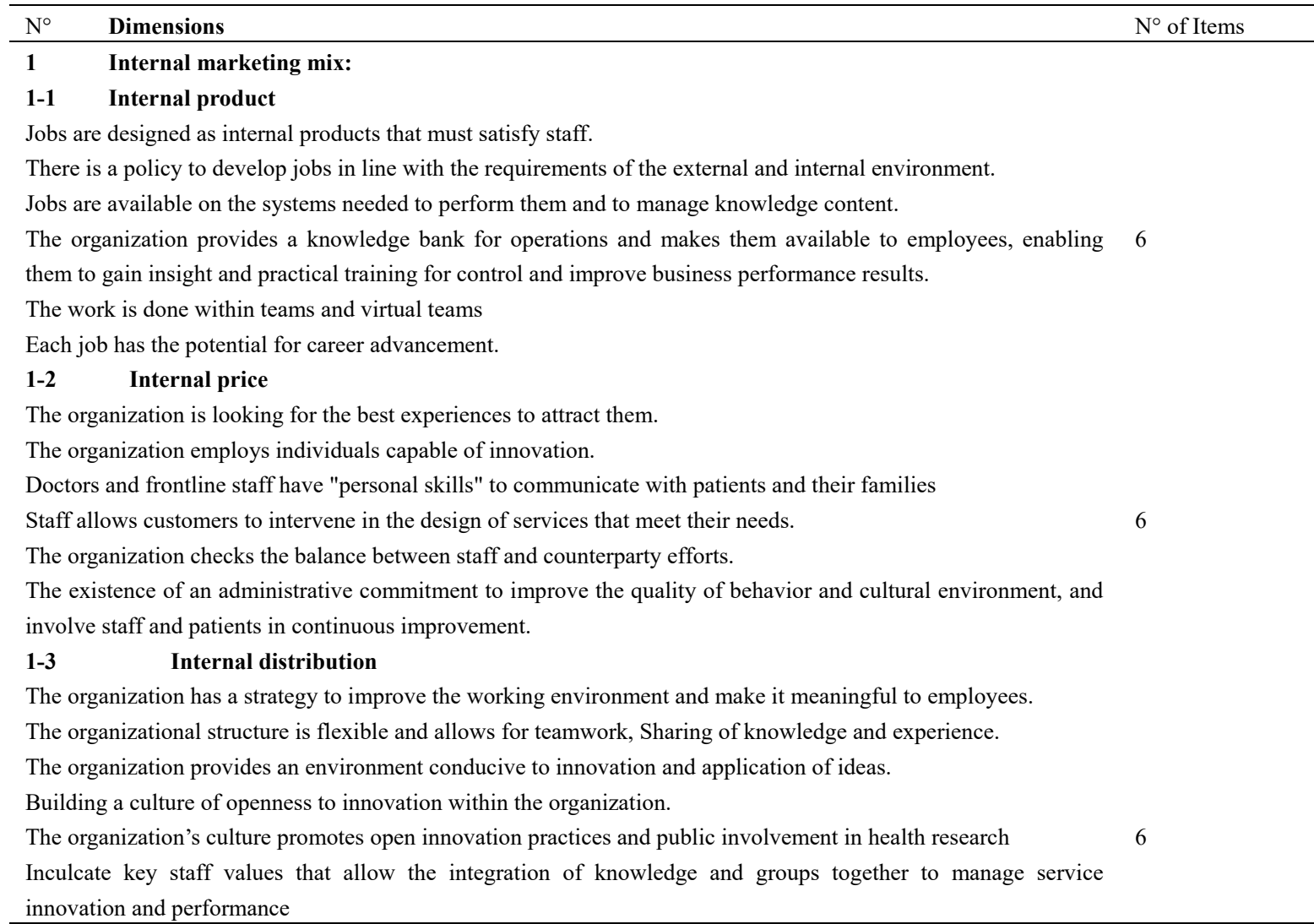




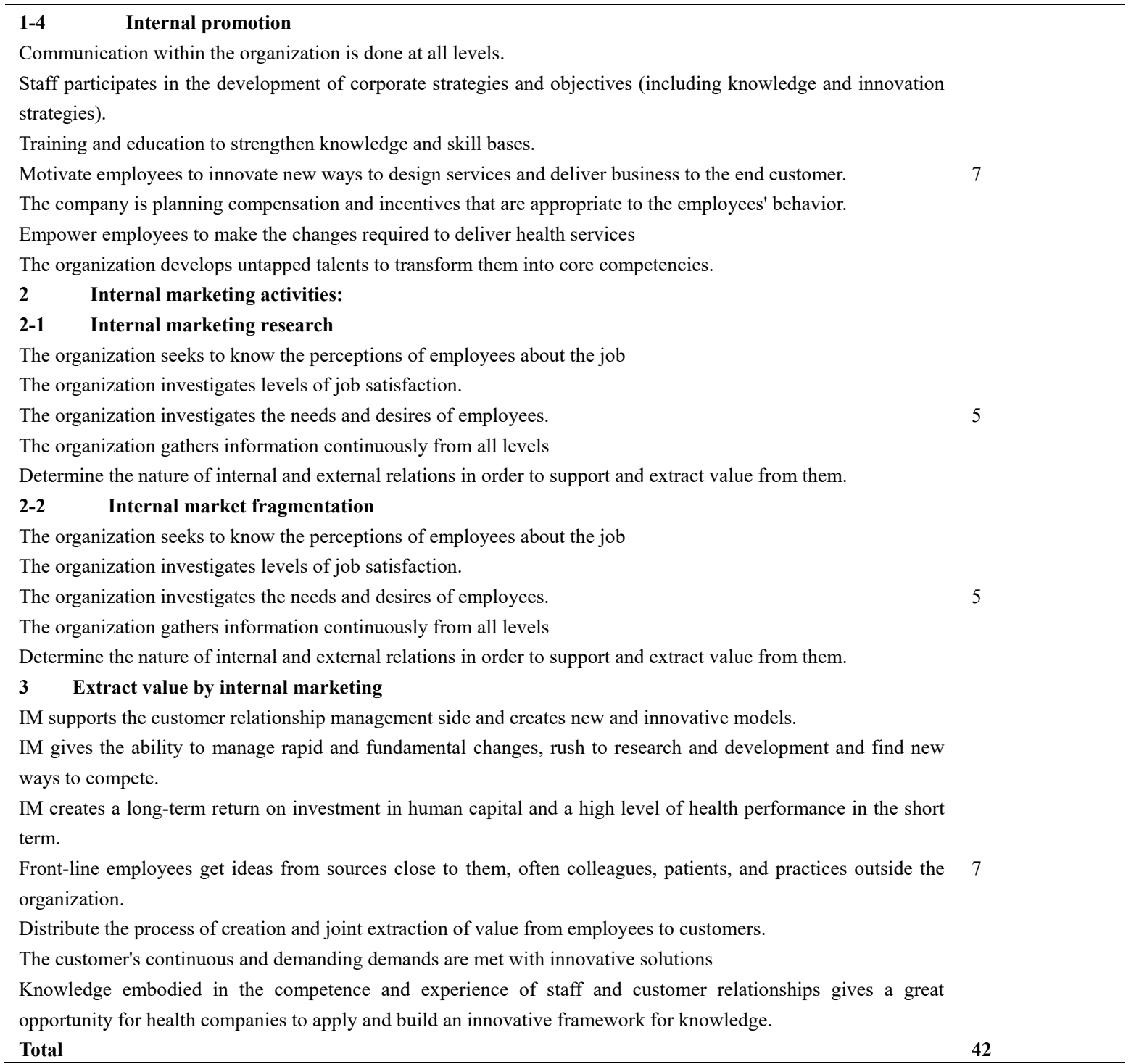

The questions in the survey were rated using Likert scale as shown in Table 2.

Table 2. The Likert scale model in answering the questionnaire

\begin{tabular}{ll}
\hline Weight & Descriptive interpretations \\
\hline 5 & Always \\
4 & Often \\
3 & Occasionally \\
2 & Rarely \\
1 & Never \\
\hline
\end{tabular}

The number assigned to the important $(1,2,3,4,5)$ do not indicate that the interval between scales are equal, nor do they indicate absolute quantities.

\section{Statistical Treatment}

First, Shapiro Wilks test of normality was using to choose tests that suite our research. 
Table 3. Shapiro Wilks test of normality

\begin{tabular}{llcl}
\hline & & Shapiro-Wilks \\
& Statistique & Ddl & Signification \\
\hline - Internal marketing mix. &, 698 & 135 &, 041 \\
- Internal marketing activities. &, 735 & 135 &, 028 \\
- extract value of organizations by internal marketing. &, 995 & 135 &, 035 \\
\hline
\end{tabular}

Table 3 shows the results for Shapiro Wilks test of normality. The p-value for each field is smaller than (0.05) level of significance, then the distribution for each field is not normally distributed. Consequently, non-parametric tests will be used to perform the statistical data analysis. The researcher would utilize the following statistical tests:

- $\quad$ Spearman Rank Correlation for Validity;

- Cronbach's Alpha for Reliability Statistics;

- $\quad$ Frequency and Descriptive analysis;

- Nonparametric tests.

\subsection{Structure Validity of the Questionnaire}

Structure validity measures the correlation coefficient between one field and all the fields of the questionnaire that have been the same level of likert scale.

The table 4 clarifies the correlation coefficient for each field and the whole questionnaire. The P-values (sig) are less than 0.01 , so coefficients of all the fields are significant at $\alpha=0.01$, so it can be said that the fields are valid to be measured what it was set for to achieve the aim of the study.

Table 4. Correlation coefficient of each field and the whole of questionnaire

\begin{tabular}{|c|c|c|c|c|c|}
\hline \multicolumn{2}{|l|}{ Spearman test } & \multirow{2}{*}{$\begin{array}{l}\text { Internal } \\
\text { marketing mix } \\
\mathbf{1 . 0 0 0}\end{array}$} & \multirow{2}{*}{$\begin{array}{l}\text { Internal } \\
\text { marketing } \\
\text { activities. } \\
\mathbf{0 . 7 6 3}\end{array}$} & \multirow{2}{*}{$\begin{array}{l}\text { Extract value by internal } \\
\text { marketing } \\
\mathbf{0 . 7 8 3}\end{array}$} & \multirow{2}{*}{$\begin{array}{l}\text { Questionnaire } \\
\mathbf{0 . 9 5 3}\end{array}$} \\
\hline marketing & Coefficient & & & & \\
\hline $\operatorname{mix}$ & signification & 0.000 & 0.000 & 0.000 & 0.000 \\
\hline & $\mathbf{N}$ & 136 & 136 & 136 & 136 \\
\hline \multirow{3}{*}{$\begin{array}{l}\text { Internal } \\
\text { activities }\end{array}$} & Coefficient & 0.763 & 1.000 & 0.613 & 0.765 \\
\hline & signification & 0.000 & 0.000 & 0.000 & 0.000 \\
\hline & $\mathbf{N}$ & 136 & 136 & 136 & 136 \\
\hline \multirow{3}{*}{$\begin{array}{l}\text { Extract value by } \\
\text { internal marketing }\end{array}$} & Coefficient & 0.783 & 0.613 & 1.000 & 0.851 \\
\hline & signification & 0.000 & 0.000 & 0.000 & 0.000 \\
\hline & $\mathbf{N}$ & 136 & 136 & 136 & 136 \\
\hline \multirow[t]{3}{*}{ Questionnaire } & Coefficient & 0.953 & 0.765 & 0.851 & 1.000 \\
\hline & signification & 0.000 & 0.000 & 0.000 & 0.000 \\
\hline & $\mathbf{N}$ & 136 & 136 & 136 & 136 \\
\hline
\end{tabular}

Note. Correlation is significant at the 0.01 level.

\subsection{Questionnaire Reliability}

\section{- Cronbach's Coefficient Alpha}

The Cronbach's coefficient alpha was calculated for each field of the questionnaire. 
Table 5. Cronbach's coefficient alpha for each field of questionnaire and the entire questionnaire

\begin{tabular}{lll}
\hline $\mathrm{N}^{\circ}$ & Field & Cronbach's Alpha \\
\hline 1 & Internal marketing mix in the organization. & 0.977 \\
2 & Internal marketing activities in the organization. & 0.658 \\
3 & extract value of organization by internal marketing & 0.652 \\
& All paragraphs of the questionnaire & 0.653 \\
\hline
\end{tabular}

Table 5 shows the values of Cronbach's coefficient alpha for each field of the questionnaire and the entire questionnaire, the result ensures equals $\mathbf{( 0 . 6 5 3 )}$ for the entire questionnaire which indicates a good reliability of the entire questionnaire.

\subsection{Empirical Analysis and Hypothesis Testing}

H1: Algerian private health organizations use" internal marketing" to "extract value", this hypothesis can be divided into the following sub-hypotheses:

H1a: Algerian private health organizations use" Internal marketing mix" to "extract value".

Table 6. Means and standard deviation for "Internal marketing mix"

\begin{tabular}{|c|c|c|c|c|c|}
\hline 1 & Internal product: & Mean & Mean\% & S.D & Rank \\
\hline $1-1$ & Jobs are designed as internal products that must satisfy staff. & 3.31 & $66.2 \%$ & 1.09 & 11 \\
\hline $1-2$ & $\begin{array}{l}\text { There is a policy to develop jobs in line with the requirements of the external and } \\
\text { internal environment. }\end{array}$ & 3.04 & $60.8 \%$ & 0.84 & 17 \\
\hline $1-3$ & $\begin{array}{l}\text { Jobs are available on the systems needed to perform them and to manage knowledge } \\
\text { content. }\end{array}$ & 4.35 & $86.9 \%$ & 0.60 & 05 \\
\hline $1-4$ & $\begin{array}{l}\text { The organization provides a knowledge bank for operations and makes them } \\
\text { available to employees, enabling them to gain insight and practical training for } \\
\text { control and improve business performance results. }\end{array}$ & 3.52 & $70.5 \%$ & 0.87 & 10 \\
\hline $1-5$ & The work is done within teams and virtual teams & 3.70 & $74.1 \%$ & 0.58 & 09 \\
\hline $1-6$ & Each job has the potential for career advancement. & 2.91 & $58.4 \%$ & 0.48 & 19 \\
\hline 2 & Internal price: & & & & \\
\hline $2-1$ & The organization is looking for the best experiences to attract them. & 2.95 & $59 \%$ & 1.37 & 18 \\
\hline $2-2$ & The organization employs individuals capable of innovation. & 3.15 & $63 \%$ & 1.24 & 14 \\
\hline $2-3$ & $\begin{array}{l}\text { Doctors and frontline staff have "personal skills" to communicate with patients and } \\
\text { their families }\end{array}$ & 2.57 & $51.4 \%$ & 1.67 & 21 \\
\hline $2-4$ & Staff allows customers to intervene in the design of services that meet their needs. & 4.39 & $87.8 \%$ & 0.49 & 3 \\
\hline $2-5$ & The organization checks the balance between staff and counterparty efforts & 4.37 & $87.4 \%$ & 0.62 & 4 \\
\hline $2-6$ & $\begin{array}{l}\text { The existence of an administrative commitment to improve the quality of behavior } \\
\text { and cultural environment, and involve staff and patients in continuous improvement. }\end{array}$ & 2.69 & $53.8 \%$ & 0.69 & 20 \\
\hline 3 & Internal distribution: & & & & \\
\hline $3-1$ & $\begin{array}{l}\text { The organization has a strategy to improve the working environment and make it } \\
\text { meaningful to employees. }\end{array}$ & 3.09 & 61.8 & 1.19 & 16 \\
\hline 3.2 & $\begin{array}{l}\text { The organizational structure is flexible and allows for teamwork, Sharing of } \\
\text { knowledge and experience. }\end{array}$ & 3.30 & $66 \%$ & 0.62 & 12 \\
\hline $3-3$ & $\begin{array}{l}\text { The organization provides an environment conducive to innovation and application } \\
\text { of ideas. }\end{array}$ & 4.31 & $86.2 \%$ & 1.08 & 6 \\
\hline $3-4$ & Building a culture of openness to innovation within the organization. & 2.54 & $50.8 \%$ & 1.57 & 22 \\
\hline $3-5$ & $\begin{array}{l}\text { The organization's culture promotes open innovation practices and public } \\
\text { involvement in health research }\end{array}$ & 2.20 & $44 \%$ & 1.07 & 24 \\
\hline $3-6$ & $\begin{array}{l}\text { Inculcate key staff values that allow the integration of knowledge and groups } \\
\text { together to manage service innovation and performance }\end{array}$ & 4.81 & $96.2 \%$ & 0.39 & 1 \\
\hline 4 & Internal promotion: & & & & \\
\hline 4-1 & Communication within the organization is done at all levels. & 3.16 & $63.2 \%$ & 1.12 & 13 \\
\hline 4-2 & $\begin{array}{l}\text { Staff participates in the development of corporate strategies and objectives } \\
\text { (including knowledge and innovation strategies). }\end{array}$ & 3.80 & $76 \%$ & 0.69 & 7 \\
\hline 4-3 & Training and education to strengthen knowledge and skill bases. & 4.51 & $90.2 \%$ & 0.50 & 2 \\
\hline 4-4 & $\begin{array}{l}\text { Motivate employees to innovate new ways to design services and deliver business to } \\
\text { the end customer. }\end{array}$ & 3.12 & $62.4 \%$ & 0.54 & 15 \\
\hline $4-5$ & $\begin{array}{l}\text { The company is planning compensation and incentives that are appropriate to the } \\
\text { employees' behavior. }\end{array}$ & 3.78 & $75.6 \%$ & 0.70 & 8 \\
\hline 4-6 & Empower employees to make the changes required to deliver health services & 2.37 & $47.4 \%$ & 0.71 & 23 \\
\hline \multirow[t]{2}{*}{ 4-7 } & $\begin{array}{l}\text { The organization develops untapped talents to transform them into core } \\
\text { competencies. }\end{array}$ & 3.78 & $75.6 \%$ & 0.70 & 8 \\
\hline & All paragraph of the field & 3.42 & $68 \%$ & 0.61 & \\
\hline
\end{tabular}


Table 6 shows the following results:

The mean of all paragraphs of the field "Internal marketing mix" equals $3.42(\mathbf{6 8 \%})$ and Standard deviation equals (0.61), so the mean is greater than the hypothesized value 3. It can be concluded that the respondents agree on the content of this dimension "Internal marketing mix" in Algerian private health organizations.

H1 b: Algerian private health organizations use" Internal marketing activities" to "extract value".

Table 7. Means and Standard deviation for "Internal marketing activities"

\begin{tabular}{|c|c|c|c|c|c|}
\hline 1 & Internal marketing research & Mean & Mean\% & S.D & Rank \\
\hline $1-1$ & The organization seeks to know the perceptions of employees about the job & 3.87 & $77.4 \%$ & 1.32 & 6 \\
\hline $1-2$ & The organization investigates levels of job satisfaction. & 4.50 & $90 \%$ & 0.50 & 2 \\
\hline $1-3$ & The organization investigates the needs and desires of employees. & 4.45 & $89 \%$ & 0.50 & 3 \\
\hline $1-4$ & The organization gathers information continuously from all levels & 4.58 & $91.6 \%$ & 0.50 & 1 \\
\hline $1-5$ & $\begin{array}{l}\text { Determine the nature of internal and external relations in order to support and extract } \\
\text { value from them. }\end{array}$ & 4.35 & $87 \%$ & 0.48 & 4 \\
\hline 2 & Internal marketing fragmentation & & & & \\
\hline $2-1$ & The organization seeks to know the perceptions of employees about the job & 3.48 & $69.6 \%$ & 0.49 & 9 \\
\hline $2-2$ & The organization investigates levels of job satisfaction. & 2.95 & $59 \%$ & 1.37 & 10 \\
\hline $2-3$ & The organization investigates the needs and desires of employees. & 3.81 & $76.2 \%$ & 0.93 & 4 \\
\hline $2-4$ & The organization gathers information continuously from all levels & 3.83 & $76.6 \%$ & 0.78 & 8 \\
\hline $2-5$ & $\begin{array}{l}\text { Determine the nature of internal and external relations in order to support and extract } \\
\text { value from them. }\end{array}$ & 4.07 & $81.4 \%$ & 0.70 & 7 \\
\hline \multicolumn{2}{|c|}{ All paragraph of the field } & 3.99 & $80 \%$ & 0.54 & \\
\hline
\end{tabular}

Table 7 shows the following results:

The mean of all paragraphs of the field "Internal marketing activities" equals $3.99(\mathbf{8 0 \%})$ and Standard deviation equals (0.54), so the mean is greater than the hypothesized value $\mathbf{3}$. It can be concluded that the respondents agree on the content of this dimension "Internal marketing activities" in Algerian private health organizations.

H1c: Algerian private health organizations “extract value by Internal Marketing”.

Table 8. Means and standard deviation for "extract value of organizations by Internal Marketing"

\begin{tabular}{|c|c|c|c|c|c|}
\hline & "Extract value" of organizations by" Internal Marketing" & Mean & Mean\% & S.D & Rank \\
\hline 1 & $\begin{array}{l}\text { IM supports the customer relationship management side and creates new and } \\
\text { innovative models. }\end{array}$ & 3.86 & $77 \%$ & 0.78 & 1 \\
\hline 2 & $\begin{array}{l}\text { IM gives the ability to manage rapid and fundamental changes, rush to research and } \\
\text { development and find new ways to compete. }\end{array}$ & 3.81 & $76.2 \%$ & 0.93 & 2 \\
\hline 3 & $\begin{array}{l}\text { IM creates a long-term return on investment in human capital and a high level of health } \\
\text { performance in the short term. }\end{array}$ & 3.47 & $69.4 \%$ & 0.95 & 4 \\
\hline 4 & $\begin{array}{l}\text { Front-line employees get ideas from sources close to them, often colleagues, patients, } \\
\text { and practices outside the organization. }\end{array}$ & 3.21 & $62.4 \%$ & 1.02 & 7 \\
\hline 5 & $\begin{array}{l}\text { Distribute the process of creation and joint extraction of value from employees to } \\
\text { customers. }\end{array}$ & 3.38 & $67.5 \%$ & 1.09 & 5 \\
\hline 6 & The customer's continuous and demanding demands are met with innovative solutions & 3.63 & $72.6 \%$ & 0.98 & 3 \\
\hline \multirow[t]{2}{*}{7} & $\begin{array}{l}\text { Knowledge embodied in the competence and experience of staff and customer } \\
\text { relationships gives a great opportunity for health companies to apply and build an } \\
\text { innovative framework for knowledge. }\end{array}$ & 3.30 & $66 \%$ & 0.77 & 6 \\
\hline & All paragraphs of the field & 3.59 & $72 \%$ & 0.78 & \\
\hline
\end{tabular}

Table 8 shows the following results:

The mean of all paragraphs of the field “extract value of organizations by Internal Marketing” equals 3.59 $(\mathbf{7 2} \%)$ and Standard deviation equals $(\mathbf{0 . 7 8})$, so the mean is greater than the hypothesized value 3 . It can be concluded that the respondents agree on the content of this dimension "extract value of organizations by Internal Marketing” in Algerian private health organizations. 
Table 9. Means and standard deviation for "All paragraphs of questionnaire"

\begin{tabular}{llll}
\hline Item & Mean & Mean\% & S.D \\
\hline All paragraphs of questionnaire & 3.67 & $73 \%$ & 0.81 \\
\hline
\end{tabular}

Table 9 shows the following results:

The mean of all paragraphs of the questionnaire "Internal marketing" equals 3.67 (73\%) and Standard deviation equals $(\mathbf{0 . 8 1})$, so the mean is greater than the hypothesized value 3. It can be concluded that the respondents agree on the content of this dimension "Internal marketing” in Algerian private health organizations.

H2: There is statistically significant relationship between "Internal marketing" and "extract value" amongst the Algerian private health organizations, this hypothesis can be divided into the following sub-hypotheses:

H2 (a): There is a statistically significant relationship between "Internal marketing mix" and "extract value of companies" amongst Algerian private health organizations.

The table (4) of spearman coefficient correlation shows Test value $=+\mathbf{0 . 7 8 3}$. The p-value (sig) $=0.00$ which is smaller than the level of significance 0.01 . The sign of test is positive, so there is a statistically significant relationship between "Internal marketing mix" and "extract value of companies" amongst Algerian private health organizations.

H2 (b): There is a statistically significant relationship between "Internal marketing activities" and "extract value of organizations" amongst Algerian private health organizations.

The table (4) of spearman coefficient correlation shows Test value $=+\mathbf{0 . 6 1 3}$. The $\mathrm{p}$-value $(\operatorname{sig})=0.00$ which is smaller than the level of significance 0.01 . The sign of test is positive, so there is a statistically significant relationship between "Internal marketing activities" and "extract value of organizations" amongst Algerian private health organizations.

The table (4) of spearman coefficient correlation shows Test value $=+\mathbf{0 . 8 5 1}$. The $p$-value $(\mathrm{sig})=0.00$ which is smaller than the level of significance 0.01 . The sign of test is positive, so there is a statistically significant relationship between "Internal marketing" and "extract value of organizations" amongst Algerian private health organizations.

H3: There is a statistically significant relationship difference amongst Algerian private health organizations toward "extract value of organizations" due to experience of organization.

Table 10. Mann-Whitney test of the fields and p-value for experience of organization

\begin{tabular}{llll}
\hline $\mathbf{N}^{\circ}$ & Field & Test value & p- value(sig) \\
\hline 1 & Internal marketing mix & -9.57 & 0.000 \\
2 & Internal marketing activities & -6.59 & 0.000 \\
3 & Extract value of companies by internal marketing & -9.17 & 0.000 \\
& All the field & -9.56 & 0.000 \\
\hline
\end{tabular}

Table 10 shows that $(\mathrm{P}-\mathrm{value}=0.000)$ of each field is smaller than the level of significance $(0.01)$. There is a statistically significant relationship difference amongst Algerian private health organizations toward "Extract value of companies by Internal Marketing” due to experience of organization.

\section{Results and Discussion}

The obtained model is show that the previous analysis of the data revealed the following Results:

- The existence of "Internal Marketing mix" in Algerian private health organizations as the mean of this dimension is $(68 \%)$;

- The existence of "Internal Marketing activities" in Algerian private health organizations as the mean of this dimension is $(80 \%)$;

- Algerian private health organizations "extract value by Internal Marketing” as the mean of this dimension is $(72 \%)$;

- The existence of "Internal Marketing" in Algerian private health organizations as the mean of this dimension is $(73 \%)$; 
- There is a statistically significant relationship between "Internal Marketing mix" and "extract value of organizations" amongst Algerian private health organizations as the correlation coefficient $(+\mathbf{0 . 7 8 3})$;

- There is a statistically significant relationship between "Internal Marketing activities" and "extract value of organizations" amongst Algerian private health organizations as the correlation coefficient is $(+\mathbf{0 . 6 1 3})$;

- There is a statistically significant relationship between "Internal Marketing" and "extract value of" amongst Algerian private health organizations as the correlation coefficient is $(+\mathbf{0 . 8 5 1})$;

- $\quad$ There is a statistically significant relationship difference amongst Algerian private health organizations toward "extract value of" due to experience of organization.

\subsection{Conclusion}

The study sought to highlight the importance of using internal marketing in extracting value for Algerian private health organizations. The first hypothesis was accepted, as Algerian private health organizations use internal marketing to extract value. The second hypothesis was also accepted, where a significant correlation was found between the use of internal marketing and the extraction of value in private health organizations by managing the knowledge of employees and customers to reach to the expected quality levels and the development of new services.

The study also accepted the third hypothesis, where there was a relationship between the experience of Algerian private health organizations and the variables of the study (internal marketing and extraction of value).

The main suggestions of the study for private health organizations include the following:

-Greater staff empowerment for open innovation practices;

-Attention to the establishment of open innovation platforms that allow employees to engage with a wide range of parties;

-Reducing the gaps between the perceptions of leaders and the front lines employees of the search for innovations.

\section{References}

Ahmed, K., \& Pervais, R. M. (2002). Internal Marketing: Tools and Concepts For Customer- Focused Management (1st ed.). Oxford: Butterworth-Heinemann.

Catalina, M., Pagalea, A., \& Cristea, A. (2014). A Holistic Approach on Internal Marketing Implementation. Business Management Dynamics, 3(11), 9-17.

David, B. (2000). Internal relationship marketing: a strategy for knowledge renewal. International Journal of Bank Marketing, 18(1), 274-286.

David, B. (2004). A Relationship Mediated Theory of Internal Marketing. Ekonomioch Samhalle, Finland. Publications of the Swedish School of Economics and Business Administration.

David, J. (2001). Principles and Practice of Marketing (3rd ed.). McGraw-Hill: Higher Education.

Farley, S. N., Andrew, M. T., \& David, S. W. (2012). Technological, Managerial and Organizational Core Competences: Dynamic Innovation and Sustainable Development. USA: Business science Reference.

Isabel, S. H., \& David, G. (2012). Internal Marketing for Engaging Employees on the Corporate Responsibility Journey. Intangible Capital, 8(2), 275-307.

John, S. W., \& Barbara, P. (2005). Cross-sector partnerships to address social issues: Challenges to theory and practice. Journal of Management, 31(6), 849-873. https://doi.org/10.1177/0149206305279601

Leonard, B., \& Parasuraman, A. (1991). Marketing Services: Competing Through Quality. New York: The Free Press.

Lionel, E. (2002). Contribution à l'analyse des déterminants de l'offre d'information sur le capital. université Paris IX Dauphine.

Michael, D. (2002). Inside-out Marketing: How to Create an Internal Marketing Strategy (1st ed.). London: Kogan Page Limited.

Mohammad, H. T., Ali, N. I., \& Majid, N. A. (2013). Investigating the Effect of Internal Marketing on employee Happiness in University of Isfahan. International Journal of Academic Research in Business and Social Sciences, 3(9), 339-350.

Philip, K., \& Keller, K. L. (2012). Marketing Management (14th ed.). New Jersey: Pearson-Prentice Hall. 
Svend, H. (2010). Marketing Management: a Relationship Approach (2nd ed.). London: Pearson.

\section{Copyrights}

Copyright for this article is retained by the author(s), with first publication rights granted to the journal.

This is an open-access article distributed under the terms and conditions of the Creative Commons Attribution license (http://creativecommons.org/licenses/by/4.0/). 